\title{
Situational Trust: How Disadvantaged Mothers Reconceive Legal Cynicism
}

\section{Monica C. Bell}

\begin{abstract}
Research has shown that legal cynicism is pervasive among residents of poor, black neighborhoods. However, controlling for crime rates, these residents call police at higher rates than whites and residents of middle-class neighborhoods, and ethnographic research suggests that mothers in particular sometimes exact social control over partners and children through police notification. Given these findings, how might researchers better understand how legal cynicism and occasional reliance on police fit together? Drawing on interviews with poor African-American mothers in Washington, DC, this article develops an alternative conception of cultural orientations about law: situational trust. This concept emphasizes microlevel dynamism in cultural conceptions of the police, expanding the literature on police trust by emphasizing situational contingency. Mothers deploy at least four alternative strategies that produce moments of trust: officer exceptionalism, domain specificity, therapeutic consequences, and institutional navigation. These strategies shed light on the contextual meanings of safety and legitimacy.
\end{abstract}

$\mathrm{T}$

he relationship between poor minority communities and the police is of urgent national concern after recent, muchpublicized incidents in Baltimore, MD; Cleveland, OH; Ferguson, MO; North Charleston, SC; Staten Island, NY; and numerous towns and cities across the United States. A May 2015 report from the President's Task Force on 21st Century Policing, convened in response to some of these incidents, identified

I am deeply indebted to Matthew Desmond, Kathryn Edin, Robert Vargas, Bruce Western, Asad L. Asad, and Yaseen Eldik for consistent support and insight. I am also grateful to Linda Burton, Marcia Chatelain, Jackelyn Hwang, Anthony Jack, Michèle Lamont, Christy Ley, Jeremy Levine, Heather McLaughlin, Dara E. Purvis, Eva Rosen, Jasmin Sandelson, Joe Soss, Alba Villamil, Christopher Winship, and participants in the Urban Social Processes Workshop, the Advanced Qualitative Methods Seminar, the Proseminar on Inequality and Social Policy, and the Culture and Social Analysis Workshop at Harvard University for invaluable feedback. I also appreciate invaluable comments from the anonymous reviewers. Caroline Lauer and ImeIme Umana provided excellent research assistance. I gratefully acknowledge funding from the Multidisciplinary Program in Inequality and Social Policy at Harvard. All errors are my own.

Please direct all correspondence to Monica C. Bell, Harvard University, Sociology, 33 Kirkland Street, William James Hall, Cambridge, MA 02138; e-mail: monicabell@fas. harvard.edu 
building police trust and legitimacy among communities of color as the first pillar and "foundational principle underlying this inquiry into the nature of relations between law enforcement and the communities they serve" (President's Task Force on 21st Century Policing 2015: 9). Correspondingly, an abundant and long-standing body of sociological literature finds that African Americans and residents of high-poverty neighborhoods are cynical about the law, distrust legal authorities, and believe police are ineffective (Hagan and Albonetti 1982; Kirk and Papachristos 2011; Sampson and Jeglum Bartusch 1998). This research concludes that those groups thus generally avoid official channels for public safety, governing themselves instead according to a "code of the street" whereby violence becomes an acceptable extra-legal strategy of protecting oneself or resolving disputes (Anderson 1999; Venkatesh 2000; see also Black 1976, 1983).

Of course, the code of the street has never been fixed or universal among poor African Americans. At the same time that urban sociologists were documenting distrust of the police and a resultant propensity toward self-help among the black urban poor, policing scholars were reporting, based on data from urban areas, that poor people called the police more often than wealthier people because they "depend upon police assistance in times of trouble, crises, and indecision," often to resolve noncriminal issues (Reiss 1972: 63). More recent ethnographies have identified poor African-American women, especially women with children, as occasional instruments of the penal state who contribute to processes of crime control, criminalization, and incarceration in disadvantaged communities by, for example, using the police to control male partners and children (Goffman 2009; Jones 2010: 39-45; Rios 2011; Venkatesh 2000). Rios (2011), in a qualitative study of black and Latino boys in Oakland, California, finds that mothers are part of a "youth control complex" along with police, probation officers, schools, community centers, the media, and other institutions. According to Rios, because mothers acquiesce to institutional messages about appropriate parenting behavior, they call the police on their children and thereby label them as criminal. Goffman (2009), in an ethnographic study of a Philadelphia neighborhood, finds that women sometimes proactively contact the police as a means of socially controlling their male intimate partners, and at other times are actively coerced to report their partner's, son's, or grandson's whereabouts through threats of arrest, loss of child custody, and physical force. Research using administrative data on police reporting has shown thateven controlling for crime rates-African Americans, women, and residents of high-poverty neighborhoods are equally or more likely to call the police than other groups (see Avakame, Fyfe, and McCoy 
1999; Baumer 2002; Bosick et al. 2012; Desmond and Papachristos 2016; Schaible and Hughes 2012). Taken together, these studies suggest that African-American women's reports to the police contribute to the criminalization and, sometimes, incarceration of African-American men.

Women's use of the police can be costly: Although contacting the police does not usually lead to arrest, it sometimes does, with unpredictable consequences for intimates and family members. When men are locked up, it separates couples and cripples family relations, making it difficult to retain cohesive relationships and financial support (Braman 2004; Comfort 2008; Suk 2009; Waller 2002; Western 2006; Wildeman and Wakefield 2014). Allowing convicted family members to stay with them can put mothers at risk of losing cash assistance and housing (Geller and Curtis 2011; Gustafson 2011). Reputational harm can result, with women labeled "snitches" for contacting police (Goffman 2009). Mothers may also fear that they are subjecting their loved ones to potential police violence. Yet remarkably little research has focused specifically on mothers' experiences and thought processes to better understand how cynicism of and reliance on police fit together. Drawing on in-depth interviews of fifty low-income African-American mothers in the District of Columbia, this paper explores the context within which, despite expressing distrust of the police and reporting negative experiences with the criminal justice system, these women develop strategies that enable occasional proactive engagement with police.

These mothers' narratives of occasional police reliance, despite their overarching distrust, urge a richer account of cultural orientations about law and criminal justice among poor African Americans. Although distrust of the law-"legal cynicism"predominates among this population, alternative cultural orientations, or frames, emerge under particular circumstances, triggered by structural and situational dynamics. This article argues that a situational approach, examining how conceptions of the police and police reporting vary depending on contexts and characteristics of particular events, is a constructive way of reconsidering how culture works in relation to law enforcement. I draw primarily from Swidler's (1986, 2001) concept of cultural repertoires (see also Hannerz 1969). Building on earlier insights about the importance of subjective interpretation of human experience as critical for understanding human action (Berger and Luckmann 1966; Blumer 1969; Thomas and Thomas 1928) and aiming to investigate connections between subjective understandings at a group level as "culture" and human action (see Geertz 1973), Swidler defines a cultural repertoire as a "bag of tricks" that 
people draw from that guide their actions. ${ }^{1}$ People use different strategies within available culture depending on characteristics of situations (2001: 33-34; see also Collins 2004; Norton 2014). ${ }^{2}$ The strategies identified in this article are part of a broader cultural repertoire about law and the criminal justice system. ${ }^{3}$ Instead of placing individuals or neighborhoods on a trustdistrust continuum, this approach examines how trust and distrust operate on a micro-level, situated within a broader cultural and structural milieu.

In this sample, four alternative strategies emerged that justified reliance on police. The first is officer exceptionalism: Mothers hold cynical views of the police as an institution but view the individual officers who patrol their neighborhoods on a daily basis as more trustworthy. Second, domain specificity: Mothers see police as effective interveners for issues occurring inside or near the home, but ineffective responders to street crime. Third, therapeutic consequences: Mothers are more likely to trust police when they believe the call will result in a beneficial outcome for the target of the call. Fourth, institutional navigation: Mothers believe that calling the police sometimes protects them from, or gives them leverage with, other institutions. Although nearly all respondents express cynical general opinions of the police, respondents use alternative conceptions when recounting incidents where they reached out to police for help.

\section{African Americans, Police, and Legal Cynicism}

The fraught relationship between poor African Americans and police is deeply rooted in American history and contemporary life, and it has birthed moments of outrage and movements for racial justice. African Americans were regularly subjected to police violence in Northeast cities at the turn of the twentieth

1 Though some scholars have criticized this model of culture as overly voluntaristic (e.g., Patterson 2000; Schudson 1989), this concept is valuable for understanding microlevel use of shared meanings, heterogeneity in the use and deployment of those meanings, and how these meanings dynamically interact with structural conditions (Harding 2007; Wilson 2009). That people use or draw on culture based on situational context does not necessarily mean that they do so rationally or consciously.

${ }^{2}$ In using concepts from cultural sociology here, I am inspired by recent papers that draw related connections (see Bell et al. 2016; Lamont and Small 2008; see also Kirk and Papachristos 2011).

${ }^{3}$ Legal consciousness scholarship, which is concerned with the daily, conflicted use of culture as a means of maintaining the hegemony of law, takes a similar approach (Silbey 2005: 329; see also Abrego 2011; Ewick and Silbey 1998; Hernandez 2010; Merry 1990). This scholarship has generally not focused on the criminal justice context. Nonetheless, perhaps another way of describing this article is that it focuses on the legal consciousness (or police consciousness) of mothers as they engage with the crime control system. 
century, sparking numerous demonstrations against police violence (Johnson 2003). In the early and mid-twentieth century, widely accepted, disproportionate police harshness in predominantly black communities contributed to blacks' greater likelihood of being arrested, charged, and sentenced more severely for crimes than whites (Chicago Commission on Race Relations 1922; see Muhammad 2010). In the mid-twentieth century and beyond, urban police readily admitted that they believed AfricanAmerican slum residents "will respond only to fear and rough treatment” (Westley 1953: 40; see Reiss 1972). Disparities in police treatment have persisted; for example, between 1980 and 1998, police were roughly six times more likely to shoot and kill young African-American male felony suspects than to shoot or kill young white male felony suspects (Brown and Langan 2001; see also Terrill and Reisig 2003). Lab-based experiments have indicated that police in larger and more heavily minority cities are more likely to shoot unarmed African-American suspects (Correll et al. 2007; see also Plant and Peruche 2005). Residents of predominantly black disadvantaged neighborhoods often suspect that police uses of force are merely displays of power, and are not born of a desire to meet communities' safety needs (Anderson 1999; Brunson 2007). Contemporary events, such as police-involved shootings of unarmed African Americans, disproportionate use of fines and warrants, and controversial policies like "stop-and-frisk," have exacerbated the troubled relationship between poor African Americans and law enforcement (Collins 2007; Harris, Evans, and Beckett 2010; Stuart 2011).

Against this backdrop, a decades-old and growing body of scholarship shows that legal cynicism, or distrust of the law and legal authorities, is a pervasive cultural orientation among African Americans (e.g., Bobo and Thompson 2006; Hagan and Albonetti 1982; Muller and Schrage 2014; Weitzer and Tuch 2004; Werthman and Piliavin 1967). Sampson and Jeglum Bartusch (1998) coined the term, defining it as "anomie about law" and distinguishing it from a subcultural tolerance of violence among African Americans (see also Short and Strodtbeck 1965). Though the term is broad, the literature has focused primarily on criminal justice. Research indicating that African Americans tend toward skepticism of the crime control system dates at least to Du Bois (1904), who argued that discriminatory practices led blacks to hold to a "firmly fixed idea that few accused Negroes are really guilty" (p. 65). The 1967 Kerner Commission, convened by President Johnson after a spate of urban riots, concluded that for many African Americans, "police have come to symbolize white power, white racism and white repression" (National Advisory Commission on Civil Disorders 1967: 10). Scholars have consistently found, regardless of the 
measure used, that African Americans have higher rates of legal cynicism and express greater dissatisfaction with police than do whites.

Other literature focuses on the ecological components of legal trust and cynicism, emphasizing how this cultural orientation arises from disadvantaged neighborhood contexts and perpetuates neighborhood-level phenomena, such as rates of violence. This ecological focus is one of Sampson and Jeglum Bartusch's (1998) central contributions. They find that, although blacks are significantly more likely to express legal cynicism than are whites, concentrated disadvantage at the neighborhood level explains a substantial amount of this variation (see also Reisig and Parks 2000). Ethnographic accounts likewise suggest that neighborhood dynamics, rather than race alone, explain distrust of the law (Anderson 1999; Goffman 2009; Werthman and Piliavin 1967). Following these insights, other scholars have shifted the unit of analysis in research on legal trust from the individual to the neighborhood, distinguishing between neighborhoods with high and low rates of legal cynicism (Kirk and Matsuda 2011; Kirk and Papachristos 2011).

The sources of cynicism are complex, but they may include police violence, nonchalance, unresponsiveness, racial bias, ineffectiveness at fighting crime, and failure to arrest those who have committed crimes (Desmond and Papachristos 2016; Kirk and Matsuda 2011; Kirk and Papachristos 2011; Sharp and Johnson 2009). Scholars posit that legal cynicism increases neighborhood violence by making it more likely for people to seek extra-legal resolutions to conflict (Black 1983; Kirk and Papachristos 2011). Anderson (1999) explains that many residents of a poor AfricanAmerican neighborhood in Philadelphia "are alienated from the police and police authority," conditions that deter people from reporting crimes to the police (p. 34). Police may be called "only in a dire emergency" (p. 321). Legal cynicism is associated with increased rates of homicide and teen pregnancy and reduced arrest for crime (Kirk and Matsuda 2011; Sampson 2012).

\section{A Social Psychological Approach}

Social psychology has contributed to the question of police trust largely through process-based research on legitimacy and procedural justice (e.g., Tyler and Huo 2002). One of the central messages of the procedural justice literature is that fairness in individual encounters with the police shape perceived legitimacy of police authority. Research on legitimacy has focused primarily on individual attitudes about legal authority, sometimes with comparison by race, but with relatively little focus on ecological 
context. Only recently have scholars begun to seriously explore, for example, the impact of social networks on legitimacy (see Papachristos, Meares, and Fagan 2012). Policing scholars have also pointed out that, while the fairness of interactions with police affects police legitimacy, people's cognitive orientations toward their neighborhood have an independent effect as well (Nix et al. 2015). Legal cynicism theory, which is grounded in racial, cultural, and ecological context, has rarely been incorporated into social psychological theories of procedural justice and police legitimacy despite cynicism's potential mediating effects on the procedural justice-legitimacy relationship (Gau 2015). The present study thus takes a more context-focused approach to legal legitimacy, exploring how a group that exists in multiple social categories based on gender, race, parenthood, and poverty make meaning of relying on the police (see Crenshaw 1989; Collins 1991; see also Obasogie 2013; Paul-Emile 2015).

\section{A Cultural and Microsociological Approach}

Legal cynicism is often described as a cultural orientation that perpetuates high crime in specific racial and ecological contexts (Sampson 2012). As such, cultural sociology offers potentially useful ways of analyzing this orientation, but it has scarcely been applied to this domain of social life. Kirk and Papachristos (2011) began the project of moving toward a new cultural approach to legal cynicism. They operationalize legal cynicism as a "cultural frame," building from Goffman's (1974) concept of frames as lenses through which people interpret the social world. This conceptualization, combined with sophisticated survey and administrative data, allow Kirk and Papachristos to capture neighborhood-level heterogeneity in mean levels of cynicism and to explore how differences in mean levels of cynicism connect to neighborhood violence.

This notion of legal cynicism as a cultural frame yields a clearer understanding of this orientation: It is a way of thinking about law and order, not an inert value (see Harding 2007). Yet, more can be learned about how the cultural orientation of legal cynicism operates by examining micro-level accounts of interactions with legal authorities, exploring the meaning-making processes surrounding specific experiences with the police rather than purely objective experiences (see Berger and Luckmann 1966; Blumer 1969; Thomas and Thomas 1928; Mead 1934). These subjective experiences and accounts are not static. As Swidler (2001) explains, the frames and strategies within people's cultural repertoires are organized around scenes, imagined situations, and stories. Shifts in situations and contexts call up different parts of cultural repertoires (pp.33-34; see also Collins 2004: 8). Accordingly, we learn more about how legal 
cynicism operates by exploring people's understandings of specific engagements with police (see Clarke 2005; Fine and Fields 2008; Norton 2014 (describing microsociological and situational approaches in the study of culture); see also Silbey 2005 (describing legal consciousness as a means of studying culture about law)). Structural, individual, and situational factors are fundamental to how culture works, and for understanding human action. Scholars interested in the relationship between poor African Americans and the police should thus explore diversity and dynamism of trust in the law: If culture is a repertoire and legal cynicism is one orientation or frame within it, what are some of the other orientations and what conditions or situations trigger them? The present study extends legal cynicism theory by using a microsociological analysis, based on qualitative data, to explore conditions under which the use of legal cynicism as a cultural frame shifts and alternative strategies that emerge depending on situational dynamics.

Research spanning subfields and disciplines has suggested that the cultural context surrounding police-community relations in disadvantaged context is variable, and that additional insight could be gained from investigating meaning-making processes. Anderson (1990), for example, describes urban black boys' distinction between "local" police and "downtown" police; local police "usually make a kind of working peace with the young men on the streets," while downtown police take an impersonal and coercive stance toward young boys. Carr, Napolitano, and Keating (2007) find that youth express overwhelmingly negative dispositions about the police but nonetheless recommend greater police involvement as a core strategy for improving their neighborhoods. Clampet-Lundquist, Carr, and Kefalas (2015) more recently describe a "sliding scale" of "snitching," such that when certain people in a neighborhood call the police under specific circumstances (for example, when a grandmother calls the police about drug dealing in her yard), young men who typically enforce anti-snitching norms may let the caller go unpunished or restrict the type of retribution to property damage, leaving the "snitch" physically unscathed. In addition to the research of anthropologists, criminologists, psychologists, and sociologists, legal academics have identified "dual frustration" with crime and police among African Americans (Meares and Kahan 1998; see also Brooks 2000; Kennedy 1997), shedding additional light on context-variant ideas about the law and formal social control.

Police relations might be especially complex, contradictory, and ambivalent among poor African-American mothers given the web of social and institutional dynamics in which they are caught. As scholarship on job search (Smith 2007), welfare (Edin and Lein 1997), eviction (Desmond 2012), and intimate partnership 
(Burton et al. 2009) has demonstrated, trust is low among this population along several axes (Levine 2013; Smith 2010). Multiple forms and levels of distrust may work in tandem. A microsociological study is well-suited for exploring the dynamics of police trust and cynicism within a population that is generally distrustful of law enforcement.

\section{Methods}

This study focuses on moments when African-American women with children engage and interact with the police. Although less likely to be arrested, incarcerated, or victims of police violence than men (Carson and Sabol 2012), women may be just as likely as men to encounter police nonchalance, unresponsiveness, corruption, threat, racial bias, or ineffectivenessall of which are believed to contribute to legal cynicism (Brunson and Miller 2006). Most current scholarship focuses on populations in the aggregate, youth, or men, particularly AfricanAmerican men; there is little focused analysis of women or mothers. Yet, this inquiry is important given research suggesting that mothers of color play a pivotal role in processes of crime control, criminalization, and incarceration in disadvantaged communities (see, e.g., Goffman 2009; Rios 2011; Venkatesh 2000). This study therefore includes narratives from African-American women with children in developing a theoretical perspective on policecommunity relations.

Interviews were conducted in Washington, D.C. Washington's police force composition, policies, and strategies, like other cities', have evolved to some degree over the past 20 years. The Metropolitan Police Department (MPD) claims to use a "communityoriented policing" model, and has emphasized relationship development as key to its police work (Buntin 2012). The MPD's racial composition reflects the demographics of the District: A majorityminority force polices the majority-minority city (which, as of the 2010 Census, was 50.0 percent African-American, 34.8 percent non-Hispanic white, 9.1 percent Hispanic, and 3.5 percent Asian) (Fontaine, Markman, and Nadeau 2010; Weitzer, Tuch, and Skogan 2008). ${ }^{4}$ MPD's stated strategy is to deemphasize minor offenses, choosing instead to focus on "bigger" crimes like drug dealing and gun-related violence (Buntin 2012).

4 Research is inconclusive as to whether minority officers perceive high-poverty neighborhoods or do police work in ways that are meaningfully better for minorities than white officers do (e.g., Brunson and Gau 2015; Cochran and Warren 2012; Eitle, Stolzenberg, and D'Alessio 2005; Moskos 2008; Sun and Payne 2004). Local police culture may predict the effect of force racial composition more fully than numbers alone. 
The study consists of in-depth, semi-structured interviews with fifty low-income African-American women with children between June 2012 and January 2013. The sample is limited to African Americans to provide a closer look at the racial group most often associated with negative views of laws and legal authorities. As a screen for income, and to make it easier to follow up with respondents, ${ }^{5}$ the sample was drawn from women who were residing in subsidized housing. ${ }^{6}$ Respondents reside in public housing (25), project-based Section 8 housing (18), private rental housing subsidized with a Section 8 voucher (6), or transitional housing for homeless families (1). Respondents range widely in age, from 20 to 61 . The sample is diverse in neighborhood racial and socioeconomic composition: Respondents were drawn from twenty-one Census tracts in all four city quadrants, selected purposely to maximize heterogeneity of age and neighborhood within the category of poor African-American mothers (see, e.g., Edin and Kefalas 2005). Among these tracts, black population ranges from 24.4 percent to 97.3 percent (2010 Census), and tract poverty rate estimates range from 12.9 percent to 53.8 percent (2008-2012 American Community Survey) (Table 1). To qualify for the study, potential respondents had to be the custodial parent of least one minor child. All respondents were born in the United States.

The study gathered data on respondents' life history and childhood experiences, romantic and family formation history, residential history, interactions with neighbors, and previous experiences with legal authority. The interviews elicited opinions about the police, reasons articulated for contacting police, and detailed accounts of each recent decision to contact the police. Although talk and action are not equivalent, interviews that elicit concrete descriptions of specific events may partially substitute for real-time observation. Interviews have the distinct advantage of capturing descriptions of events over long periods of time and are a powerful tool for understanding perceptions. All but three

5 Subsidized housing residents may be somewhat more stably housed than poor people who rent on the private market.

6 This sampling frame may be a limitation: Most poor American families do not receive housing assistance (Desmond and Bell 2015). No study of police-community relations of which I am aware compare outcomes according to whether people live in public housing, receive a housing subsidy, or rent unassisted on the private market. However, these studies often compare neighborhoods with "concentrated disadvantage"-a measure that includes benefit receipt - to those without such disadvantage (e.g., Kirk and Papachristos 2011; Sampson and Jeglum Bartusch 1998). Qualitative studies of law, culture, and police-community relations are often based in neighborhoods where a significant portion of the housing stock is comprised of subsidized housing (e.g., Jones 2010; Venkatesh 2000; Websdale 2001). Legal cynicism theory is thus implicitly founded upon a residential context reminiscent of this sample's. Nonetheless, future research might examine whether and how subsidized residential context matters for police trust. 
Table 1. Sample Characteristics

\begin{tabular}{|c|c|c|}
\hline Characteristic & Mean & Range $\dagger$ \\
\hline Age & 40.54 & $20-61$ \\
\hline Years in Current Residence & 8.80 & $0.33-24$ \\
\hline *Tract Poverty Rates & 35.58 & $12.8-57.3$ \\
\hline Below $30.0 \%$ & 0.36 & \\
\hline $30.1 \%-40.0 \%$ & 0.18 & \\
\hline $40.0+\%$ & 0.46 & \\
\hline${ }^{+}$Tract Black Population & 77.01 & 24.2-97.3 \\
\hline Below 30.0\% & 0.02 & \\
\hline $30.1 \%-50.0 \%$ & 0.24 & \\
\hline $50.1 \%-85.0 \%$ & 0.08 & \\
\hline $85.0+\%$ & 0.66 & \\
\hline \multicolumn{3}{|l|}{ Children } \\
\hline Number of Children & 3.36 & $1-12$ \\
\hline Age Oldest Child & 19.33 & $0-41$ \\
\hline Age Youngest Child & 9.40 & $0-18$ \\
\hline Has Daughter & 0.84 & \\
\hline Has Son & 0.80 & \\
\hline \multicolumn{3}{|l|}{ Marriage } \\
\hline Currently Married & 0.18 & \\
\hline Never Married & 0.70 & \\
\hline \multicolumn{3}{|l|}{ Education } \\
\hline College Graduate & 0.12 & \\
\hline Some College or Trade School & 0.20 & \\
\hline High School Diploma or GED & 0.40 & \\
\hline Less than Diploma or GED & 0.28 & \\
\hline Total Years of Education & 12.20 & $8-14$ \\
\hline \multicolumn{3}{|l|}{ Public Assistance } \\
\hline$T A N F$ & 0.56 & \\
\hline$S N A P$ & 0.90 & \\
\hline SSI & 0.26 & \\
\hline Employed & 0.24 & \\
\hline Ever Sued for Eviction in DC & 0.68 & \\
\hline${ }^{\times}$Number of DC Eviction Suits & 4.33 & $0-53$ \\
\hline Ever Arrested & 0.54 & \\
\hline Ever Incarcerated & 0.18 & \\
\hline Ever Investigated by Child Services & 0.52 & \\
\hline
\end{tabular}

Notes: *American Community Survey five-Year Data, 2008-2012.

${ }^{+} 2010$ U.S. Census Data.

${ }^{\times}$This mean includes those who have never been sued for eviction in D.C. Limited to those who have been sued, the mean number of cases is 6.42 . Omitting an outlier of 53 suits, the mean drops to 4.97 .

${ }^{\dagger}$ Ranges are 0-1 unless otherwise specified.

interviews took place in the respondent's home or the home of a close relative or neighbor.

Neighborhoods in Washington were selected using Census data and information from the US Department of Housing and Urban Development and the DC Housing Authority, aiming to identify high-density public housing projects or site-based Section 8 developments across quadrants. The researcher posted study recruitment flyers in complexes or at nearby bus stops, which yielded 25 respondents. Twenty-one respondents were recruited through managed snowballing; respondents could refer up to three participants. The study also randomly sampled from one project-based Section 8 housing project, generating four interviews. Respondents were compensated with $\$ 25$ cash for one interview. 
At the close of each interview, and in the neighborhoods during data collection, field notes were taken to identify emerging themes. Interviews were digitally recorded and transcribed verbatim. After listening to the audio recordings and reading through entire transcripts, Atlas.ti was used to code the transcripts in multiple phases, using open, thematic, and selective coding, beginning with broad themes and then focusing on narrower themes as the coding process continued (Charmaz 2006; Glaser and Strauss 1967; LaRossa 2005). I present the most salient themes in the findings, though other themes (including neighborhood racial context, examined in the discussion) emerged more tentatively. With research assistants, I analyzed the transcripts, assured the validity of the argument, and compiled quantifiable descriptive characteristics (Table 1). Using electronic court records, we checked the validity of information obtained during interviews about arrests, criminal cases, and housing cases.

\section{Findings}

This article shows how a sample of poor African-American women with children understands their interactions with police. Legal cynicism is high in this sample: Only three respondents made uniformly positive statements about the police, and eight respondents made only negative statements. Thirty-nine of 50 respondents, however, made a combination of positive, negative, and neutral statements about the police. The number of police calls is an imperfect measure of police reliance; police are so heavily present in most respondents' neighborhoods that they can seek assistance without placing a call. As one respondent explained, "The police be around here enough." Moreover, respondents-like the general populace (see, e.g., Bosick et al. 2012; Reiss 1972:66-67)—do not report most incidents that could warrant a police call. Yet 33 of 50 respondents admitted to calling the police at least once. Respondents in their twenties were more consistently cynical of police than the oldest respondents. ${ }^{7}$ Nonetheless, four of nine respondents in their twenties admitted to occasionally calling the police.

This article argues that one way to understand the police relationships of poor African-American mothers is by examining conditions under which these women defy their own and others' expectations by relying on police, thereby engaging in situational

7 The age gradation is expected given a long line of research finding that AfricanAmerican youth and young adults have more negative views of police than older adults do (see Du Bois 1904; Carr, Napolitano, and Keating 2007). 


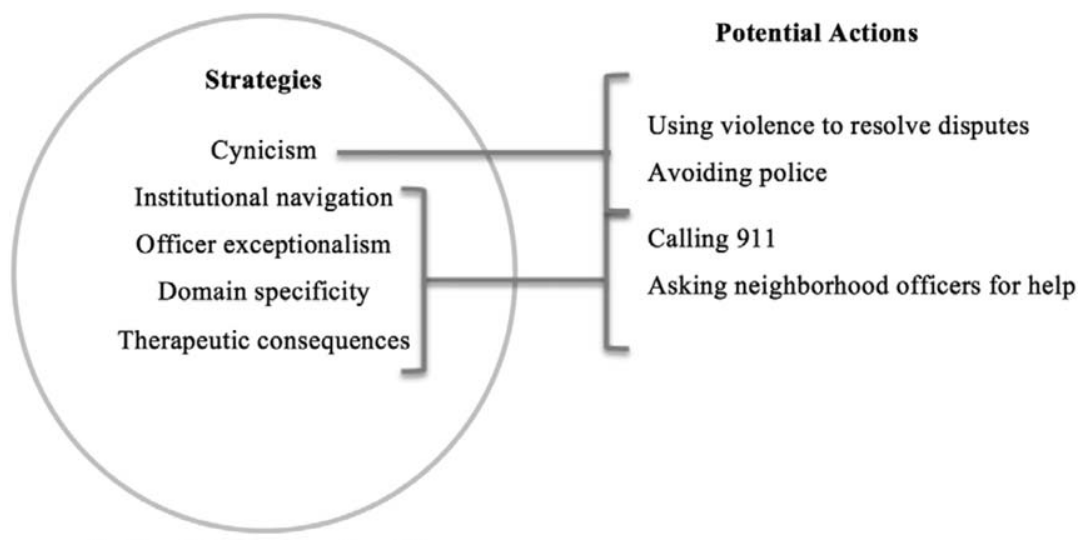

Cultural Repertoire about Law

Figure 1. Conceptual Model.

police trust. Crucially, "trust" here does not imply a total sense of faith. Instead, it is akin to what scholars call "strategic trust" (Smith 2010; Uslaner 2002) or "suspended trust" (Burton et al. 2009). It includes some expectation of reliability (see Giddens 1990), and it requires risk (Luhmann 1979), but it is limited and circumstantial. Writing on low-income mothers' trust in intimate partnerships, Burton and colleagues (2009) explain that couples with suspended trust took on "very limited and specific roles in each other's lives"; "the emotional risks of the arrangement were low and the duration limited" (p. 1115). Here, as there, trust is tightly attached to context, such that the respondent who says, as a general matter, that "Police are crooked," might trust a police officer to escort a troublemaker away from her home, or may over time develop trust in the reliability of specific officers without trusting the institution writ large. There are at least four alternative cultural strategies through which women engage with the police. As noted above, they are (1) officer exceptionalism; (2) domain specificity; (3) therapeutic consequences; and (4) institutional navigation. The conceptual link between these strategies and mobilization of police is visualized in Figure 1.

Neither the strategies nor the actions in the figure above are exhaustive. The figure illustrates, however, that multiple strategies exist within a cultural repertoire, and that each strategy might suggest different actions. Although strategies can be identified separately, they often intersect and overlap.

\section{Officer Exceptionalism}

In line with previous research on disadvantaged African Americans, respondents are deeply wary of police. They see police as corrupt, 
biased on the basis of race and class, and nonchalant about poor African Americans' lives. However, many respondents (20), despite making cynical statements about the police in general, decouple "the police" as an institution from officers as individuals. Rather than projecting positive feelings about individual officers onto the institution they represent, these relationships often remain localized. This decoupling is an increasingly available strategy in an environment where police are part of daily interaction.

Donna, 50, initially reacted to a question about her perspective on the police with, "They suck," and she then described police corruption observed in "the crack joints" and heard about through local news. Yet as her story unfolded, she revealed a casual relationship with an officer who patrols her neighborhood whom she nicknamed "Andy Griffith":

[How do you think about police?] They suck... I mean, some will help if you need help. They're human beings. I watch the news on the TV, and some of them have done some dumb things. A lot of them get away with it. I have seen some of them come out here and rob the crack joints. They take the money. I see that a lot of times, and it will be around Christmas time... [So you said they're around here a lot?] Yeah, there's one here occasionally. I call him Andy Griffith. [So it's like an older guy?] Yeah, he's older, but he's nice. A lot of people don't like him because he ask questions, but he's just asking questions because he's talking to them. A lot of people think it's because he's police. He'll drive around and beep, and sometimes he'll sit on the corner. He's all right. It's people.

This response should be viewed in light of Donna's background with the crime control system. Over the past two decades, she has been arrested on several criminal charges. Most were dropped, but she served two stints in prison for drug possession. Now, she lives in a neighborhood that she describes as "terrible," and explains that, "Living here, I've seen a lot of killing." When talking with the police now, her guidelines are simple: "I respect them. I talk to them. That's how I learn. I ask questions." The police have been continually present in her life, in multiple ways, for decades. It is thus unsurprising that she has a somewhat more complex set of interactions with officers than cynicism theory alone would predict.

Pam, who at 44 is recovering from a decades-long crack addiction, believes that a lot of police officers are "doing crooked stuff." Nonetheless, she takes time to get acquainted with the officers who work in the vicinity of her apartment building: 
We have Metropolitan working here, and I got to know all of them. I used to take them to dinner. They're fine with me. I feel like they're here to protect us. [Did you feel this way when you were using?] Yeah. I was still talking to them. They knew you were using. It wasn't about who was using, but it was about who was selling it.... They're pretty good. I mean, the ones that ain't doing crooked stuff. [Do you feel like a lot of them are doing crooked stuff or just a few?] A lot of them because we've always got them on the news doing stuff. Every time you turn on the news they're doing something. I know one time they had four of them up in the 4 th District selling drugs. Then they had the police that killed that little boy up in Southeast a couple years ago. The boy had no gun. You know what I'm talking about? There's a lot of police brutality going on out there, a lot of crooked stuff. What can we do?

In Pam's words, there is a sense of resignation to widespread police violence and corruption. Yet in her own neighborhood, police officers have been "fine." Despite her concern that the police are "crooked," Pam has reached out to them on several occasions, particularly for managing relations with her PCP-addicted adult son. Pam explains, "I just got tired of it. Enough is enough." She was particularly worried about his tendency to punch walls and break furniture because property damage could spark eviction from her Section 8 apartment (a well-founded fear given that Pam has been sued for eviction more than 20 times).

When I asked women about "the police," they consistently drew distinctions between the police as an institution-almost universally expressing cynical views-and the beat officers they encountered on a daily basis. Social psychologists might explain this tendency using a general individuation model: Although respondents might hold negative views of police as any out-group, they begin to individuate officers with whom they have regular contact (see Shriver and Hugenberg 2010). Due to shifts in law enforcement since the 1990s that have intensified police presence in highcrime neighborhoods, the women in this sample constantly encounter police as a part of regular life. As Tara explains: "Sometimes they come out here and do stuff with the kids at the Rec... It's not all the time they're around here that they're arresting people." Although other scholars have recognized the presence of a few "good cops" in the neighborhood (e.g., Anderson 1990; Rios 2011: xii), I argue that these multifaceted experiences produce contradictions within women's institution-level opinions of the police and their individual-level perspectives on officers, thereby making occasional reliance on police more possible. However, even positive 
Table 2. Characteristics of Reported Police Calls

\begin{tabular}{lcc}
\hline Characteristic & $\begin{array}{c}\text { Number of } \\
\text { Contacts (N = 54) }\end{array}$ & Percentage \\
\hline Incident Type & 22 & 40.7 \\
*Intimate Partner Violence & 13 & 24.1 \\
Other Family Disputes & 6 & 11.1 \\
Neighbor Disputes & 3 & 5.6 \\
Vandalism & 3 & 5.6 \\
†Drug Use & 1 & 1.9 \\
Drug Dealing & 6 & 11.1 \\
Other (e.g., child hit by car, prostitutes) & & \\
& & 11.1 \\
Sphere of Incident & 6 & 24.1 \\
Street/Neighborhood & 13 & 64.8 \\
Order-Maintenance Around Home & 35 & 11.1 \\
Familial/Domestic & & 33.3 \\
Perpetrator Relationship & & 35.2 \\
Stranger & & 14.8 \\
Neighbor or “Associate" & 6 & 3.7 \\
R's Romantic Partner & 18 & 53.7 \\
Other Family Members & 19 & 8 \\
Intimates and Relatives (partner plus child plus family) & 2 & 29 \\
\hline
\end{tabular}

Notes: *Includes against $\mathrm{R}$ and others.

$\dagger$ I report here only when $\mathrm{R}$ indicated that drugs were the reason she called the police. Incidents involving drugs where $\mathrm{R}$ indicated that she called for another reason are omitted from this count.

${ }^{\times}$Includes romantic partners of R's children and neighbors.

encounters that create trust in specific officers, or that might be perceived as procedurally just (see Tyler and Huo 2002), stop short of building a sense of legitimacy or trust in the broader system of crime control. The stickiness of institution-level cynicism may be due to the collective memory and current-day collective experience of police mistreatment (see Gau 2015).

\section{Domain Specificity}

Respondents believe that calling the police is occasionally a reliable strategy for regaining control of situations they perceive as a direct threat to themselves or their children. Familial or public order domains close to or within the home are where police can be trusted most. Police are deemed fairly efficacious in escorting away violent partners, finding runaway children, or quieting disruptive neighbors. However, they cannot be trusted to protect respondents or their families from violent street crime. This belief is reflected in respondents' reported police contacts, with 35 of 54 contacts occurring in response to issues inside the home, 13 for order maintenance in the periphery of the home, and 
only six contacts for street crimes. Only one respondent admitted to reporting violent crime outside the home (Table 2$){ }^{8}$

Tiffany, a 34-year-old mother of three, explains that calling the police on drug users in the hallway immediately outside her door has been an integral strategy for calming the environment. When she first moved to the neighborhood 13 years ago, she perceived the area immediately outside her apartment as loud and dangerous: "We had dudes hanging all outside, smoking in the building, drinking in the building, doing whatever they wanted to do." This has since changed; her group of apartments is now "the quietest court." Tiffany credits this change to a collective neighborhood effort to first ask them to leave, and then to call the police: ${ }^{9}$

The people that have moved in these buildings now, we don't want any of that in here. We don't want smoke or crack...We tell them, "You're not respecting our kids, so why should we allow you to do what you're doing? 'Cause if you were respecting our kids, you wouldn't do that crack in the hallway or be making all of this noise at night. You know it goes up under the door, and the kids are in the house." So we call the police. [How often?] If you see them in the hall, all the time. We call them.

Although Tiffany uses the police in this way, she expresses a general contempt for them. When asked to describe her relationships with police, she responds: "The police around here, always negative. Always negative." She goes further: "You have to know your rights, because if you don't know your rights, the police will get over on you...That's why people are always saying, 'Fuck the police." Her words are a clear expression of police cynicism. Yet when drug users are in her hallway, she and her neighbors respond by calling the police. It is, of course, difficult to know whether the changes Tiffany has observed over time are attributable to her and her neighbors' police-reporting efforts or to other factors, such as increased patrolling, general neighborhood change, or transitions in the local drug market. What is important is that she believes her home is safer because she contacts the police.

8 Table 2 likely undercounts the actual number of police contacts from respondents. Respondents who described making multiple calls to police usually could not give a precise number, and would instead say something like "many times" or "all the time." Because I could not get a precise number, I used the most conservative estimate, including only contacts that the respondent described in detail as distinct incidents. The maximum number of detailed contact descriptions per respondent is 6 ; the modal number is one.

${ }^{9}$ This is a rare example of collective efficacy (see Sampson 2012). Usually, policereporting is a decision made alone. 
Vera, a 39-year-old mother of 2, is concerned about rampant drug dealing in the courtyards and playgrounds of her apartment complex. Despite her own years dealing drugs just outside of D.C. in Montgomery County, Maryland, she is now convinced that the drug trade is detrimental to her neighborhood: "If I could do something about the drug dealers, I would, but I can't," she said. She believes the police already know about drug dealing but choose to ignore it. Initially, Vera claimed that she would never call the police on anyone: "I have kids," she explained. But Vera recently called the police to respond to a noisy altercation between the woman who lives above her and her boyfriend. She had heard the couple fighting before and asked her neighbor to keep it down: "I wasn't scared they would hurt me or anything because I had told her I didn't appreciate all the noise. I have to get up and go to work in the morning. My kids have to go to school." Vera wanted the noise to stop, and she "was getting real worried because the noise was getting real loud. The banging was getting real serious." Her call was successful: Vera has not heard the noise since. (She does not know the status of her neighbor's relationship.) Here, the perceived cost of reporting was low, and she thought the police, despite choosing to ignore drug dealing, might effectively intervene in a domestic altercation. This report was also tethered to her maternal goals: She reported the noise because, among other things, "my kids have to go to school." Reporting drug dealing would be antithetical to that duty: "I have kids."

Familial or public order domains are where police can be most trusted and effective. When it comes to violent crime, however, women see calling the police as a useless and potentially dangerous strategy. In keeping with now-common wisdom on crime reporting, women do not willingly "snitch" about violent crime. Nickie explains the danger of reporting violent street crime to police:

Around here, it's you snitch and they're going to look for you and kill you. It's a couple of people around here just got killed around here and shot in the head, and a couple of people snitched around here, and now they're in the Witness Protection Program. One of the people that snitched was like family to me. When she left, she went back to New Orleans, but they was coming back to me and saying, "If we see her get off the plane we're going to kill her." She can't come back to D.C. because they already got a hit on her. Around here, if you snitch on somebody, especially if you go to court and testify, you're a done deal. 
Yet, in another situation, Nickie called the police on her daughter's father, who struggles with alcoholism, because he was drinking heavily. Foregrounding the therapeutic consequences finding below, she thought having him arrested might get him into treatment.

Similar repudiations of snitching, or being "hot," were present throughout the sample. However, the social meaning of "snitching" about violent crime and "snitching" about family violence, noise, or truancy are divergent. The powerful script against police-reporting applies most strongly to drug trafficking and violent crime, which are more likely to have enforcement weight of youth and gangs behind them, and less to other crimes (see Clampet-Lundquist, Carr, and Kefalas 2015).

Domain specificity is thus an important pathway to police reliance. Earlier research noted the poor's tendency to call the police about noncriminal matters, arguing that the poor may lack awareness of more appropriate or proportionate modes of recourse for these types of matters (Merry 1990; Reiss 1972). However, by virtue of living in heavily policed neighborhoods and having close contact with the crime control system, ignorance is rarely a reason for domain specificity in this sample. Instead, respondents made strategic choices to call the police to protect the home and rarely for crimes that occurred beyond their home's immediate perimeter, even if they were aware of criminal activity. As Etrulia, a 56-year-old mother of twin boys, explains: "I see stuff, and I don't see stuff, ok? That's the way I roll. This is my house. You do whatever you want as long as it don't touch my house." My results show that women are deeply concerned about crime in their neighborhoods but engage the police to halt crime closer to home. Women may not consistently report crimes like domestic violence to police (see Felson et al. 2002), but they are more likely to report these disturbances than street crimes.

\section{Therapeutic Consequences}

When women call the police, they are often turning in people about whom they deeply care-intimate partners and children (see Thomas 2013). One way respondents explain these calls is by emphasizing potential therapeutic consequences of police involvement, such as getting into social service programs or interrupting destructive patterns. Of thirty-five reported police contacts that deal with issues in the home, respondents spontaneously articulated rehabilitative rationales for 12 of them.

Shay, a 35-year-old mother of 5, grew up in a particularly crime-ridden housing project during the peak of the crack cocaine era. On one hand, she believes in a "street code" against 
calling the police: "When you grow up like I did, some stuff is almost like the law...You don't always call the police on people." Yet she has called the police on multiple occasions to help friends facing domestic violence and to control her teenaged son and daughter. Her son is currently in juvenile detention in another state. She called police because her son was "being a disrespectful child—talking back and being aggressive, not listening":

At the end when he was not going to court, he had bench warrants for his arrest because he wouldn't go back to court on the charges. They were looking for him. I couldn't get him to turn himself in himself. He looked at it like I had set him up because I had to get him to the house for them to get him. He was real reckless. I just didn't want him to harm himself or to harm someone else. I didn't want him to get into some serious trouble because he was hanging with the wrong people. One of the persons he was hanging around with is now doing 30 years.... Can you imagine if he was on the street? I had to explain to him why I had to do what I had to do when I was really able to sit down with him-"This is why mommy did this." It makes sense to him now. He knows now when hearing about all the other things that were going on with the rest of his friends and how they started to get into serious trouble. They were doing robberies now and serious things. If he was home right now, he'd be doing the exact same thing that they're doing. He knows now that mommy saved him.

Despite her belief that contacting the police is generally inappropriate for someone who grew up in a poor neighborhood, Shay justifies calling the police on her son as an effort to "save him." She sees calling the police as an interventionist parenting strategy, an effort to hold her son accountable for previous wrongdoing, divert him from law-breaking peers, and warn him of the potential consequences of continued criminality. Although research indicates that serving time in juvenile detention hardens young men and potentially increases the likelihood of recidivism (Nurse 2002), Shay is hopeful that by interrupting her son's spiral into deeper delinquency, she has helped reset his future. Many mothers are likely aware of these risks. Yet, structural and situational context nonetheless encourages them to make the difficult choice to trust the crime control system, hoping that calling the police will provide a path toward redemption.

Problems arise when respondents seek therapeutic consequences but receive punitive ones or harsh treatment instead. Angie, a 
39-year-old mother of three, was shocked at her exchange with a police officer who responded when she called the police on her estranged husband. After an argument with her husband that involved threats of violence, Angie told the police that she did not want her husband around their children. When police arrived, the officer allegedly told Angie that her home was immaculate and it looked like there were no household problems. Angie felt that the officer "tried to condemn" her:

She took me into my back room and she was like, "Why are you calling the police on your husband?" I said, "Because I felt threatened." She said, "You know, your house is immaculate. People whose houses this clean don't usually have any type of issues going on like that in their home." I'm just looking at her like-? When someone says something I just play it off. Ok, that's what you think. She's like, "Where's your family? You don't have no one to help you?" I said, "Ma'am, my family is not here. I don't have a support system." ... She kept saying that, and I said, "Ok, ma'am, are you finished?" I started walking to the door, and she wanted to keep going on and on, but I just tuned her out because I think she wanted to provoke me. I feel like some women cops like that. She wanted to provoke anger out of me so I would pursue an argument with her. She'd have been like, "Ma'am, you're going to jail." I wasn't going for that.

This exchange was disappointing, but it did not deter Angie from calling the police the next time she had an argument with her husband. She was happier with that outcome: Calling the police led to counseling for her son who has mental health challenges. After the call, "another social worker came, and she listened to me and was excellent... She was basically giving me advice as far as helping with my son getting into therapy and managing his behavior." This call produced the "support system" that Angie otherwise lacks.

Disadvantaged mothers have limited options for parental support outside the crime control system. What Bourdieu (1998) calls the "left hand of the state"-income support, housing, child services-is often perceived as precarious and punitive. The criminal justice system-the "right hand"-sometimes provides more robust support than social services does (see Garland 2001). But police are not social workers. Calling the police on neighbors about minor disagreements escalates conflict and, in the aggregate, may erode neighborhood trust. Calling the police on family members deepens the reach of penal control into communities and homes. 


\section{Institutional Navigation}

Many disadvantaged African-American mothers parent in the shadow of social services bureaucracies (Gilliom 2001; Rios 2011; Roberts 2002; Sykes 2011). Crime control and social welfare are gendered parallel structures, men monitored by the criminal system and women by the social welfare system (Goffman 2009; Soss, Fording, and Schram 2011; Wacquant 2009). Poor families' involvement with other state institutions is one surprisingly unexplored factor in their relationships with and use of police. Respondents identified social welfare institutions as a justification for more than one-quarter of contacts to report children or neighbors.

Janice called the police to move from a violent public housing project to a safer one. After her son was murdered about a decade ago, DCHA moved her to a smaller apartment. However, they moved her to a different complex notorious for violence. In this neighborhood, Janice says, "Every time I turned around, someone was trying to jump my daughter." Once there was a large crowd threatening to attack her daughter, and Janice intervened. In response, someone threw a chain at her but missed. Although Janice ordinarily uses extra-legal approaches to address neighborhood disputes, she decided to be more strategic this time:

I went through the police and let them handle it. I moved that way... I reported them. You get a report number, and Crime Victims helps you. For young people, for us citizens, there are a lot of things that the government has that we don't know and we're too lazy to get stuff. Like you're doing research to find out things? I'm a researcher. Anything to better myself, to better my child's life, I'm going to find it... The girl was arrested, so she was a threat to me and my child. They moved me.

Janice used the police for institutional navigation despite her general cynicism about police. She claims to "keep my distance" from the police "because a lot of them crooked... police lie. They twist the truth." Here, calling the police was a shrewd response to Housing Authority policies that incentivize calling the police. ${ }^{10}$

10 The relevant Housing Authority policy is D.C. Municipal Regulation 14-6402, which requires that public housing transfer requests due to "situations of a life threatening medical or public safety nature" are given first priority. D.C. Mun. Reg. tit. 14 § 6402.18 (a) specifies that "these life-threatening conditions must be documented and verified." 
Tory also called the police about a dispute with a neighbor. She rushed to report her neighbor before her neighbor reported her: "I tell [police] so they can ruin that person... On our lease, one violation is fighting. You will get put out of here." The struggle to retain housing plays a role in women's decisions to report crimes to police (Desmond and Valdez 2013). This is a particularly potent issue in D.C., where rapid socioeconomic and racial change has drastically reduced the affordable housing stock. Retaining subsidized housing may be the only way most respondents can continue to live in their home city. As seen in Table 1, 68 percent of the sample has been sued for eviction in DC. ${ }^{11}$ Housing insecurity is an institutional constraint that can override legal cynicism and convince a mother to call the police. Income insecurity may also factor into decisions to report crime, particularly when illicit activity provides economic support (Pattillo-McCoy 1999; Venkatesh 1997).

The incidents above might be particularly salient in a sample drawn from residents of subsidized housing. However, the most commonly mentioned fear was losing custody of children, a concern that is not peculiar to assisted renters (see Roberts 2002). More than half of respondents had been subject to a child protective services investigation. Only a small number of these investigations resulted in even brief removal of a child from the home, but there is nonetheless a perception that child removal is pervasive: As Althea commented, losing one's children "is common in an urban neighborhood." Stories and proverbs about avoiding child removal abound, with some respondents worried that if their home is disheveled, or if their kids publicly misbehave, their children may "go into the system and never come out."

It sometimes seems that calling the police helps mothers avoid this fate. Daniqua, 34, was having trouble keeping track of her teenage son. He was rarely home, and she could not ensure that he was attending school. Child and Family Services (CFSA) had already investigated Daniqua because of another school attendance issue: Her daughter had been absent from school for several weeks after contracting Kawasaki syndrome. According to Daniqua, the school reported the extended absence to Child and Family Services two days after her doctor's note expired. A lesson Daniqua learned from this experience is that she should avoid truancy at all costs. Not only does truancy trigger a child welfare investigation, it could also lead to a criminal misdemeanor conviction. As do more than half of U.S. states, the District prosecutes

11 This does not count potential suits in other states or some younger respondents who have never held their own lease. Also, because my sample does not include unassisted renters, it may not reflect the full scale of the housing affordability problem. 
parents for their children's truancy under educational neglect statutes. ${ }^{12}$

After years of calling police to track her son, Daniqua and her husband contacted the MPD's Youth Investigations Branch, which manages programs targeting youth who exhibit deviant behavior. Her son now has a probation officer who has imposed a curfew, regularly tests him for drugs, and ensures that he is at school. Daniqua is pleased with her decision to call the police on her son. However, she has misgivings about the police generally, lamenting their failure to get involved in events that led to her brother's 2010 murder: "If the police would have intervened, my brother would have been still alive... Why didn't you go down there and tell them to break it up? [The officer] just let it go on, like 'It's the "hood and who gives a damn?" There is a palpable bitterness in Daniqua's voice as she tells this story. Yet despite this and other disappointments, the institutional context surrounding her son's unruly behavior left her with few alternatives to the police department. Ernestine expresses frustration at this doublebind of high parental liability and low parental autonomy: "You know, if the kids don't go to school, they lock the parents up. You can't make a kid go to school!... The government isn't really letting you raise your kids." By calling the police, mothers can signal adequate parenting effort to the state, thereby avoiding their most dreaded outcomes.

Some respondents explain that fear of social welfare agencies dissuaded them from calling the police when they otherwise might contact them. Calling the police can precipitate a child protection investigation. Katina, for example, called the police when her daughter's father Byron threw a lamp in an argument over visitation. The police advised her to pursue a restraining order, and she did. A week later, after receiving a tip from Byron's mother, CFSA investigated her. After finding evidence of marijuana use, CFSA removed Katina's children for a week, a time she tearfully refers to as "the worst seven days of [her] life." Depending on the agency at issue and the circumstances of the case, mothers might rely on police or avoid them. The goal in this navigation process is living up to the full promise of motherhood: maintaining custody of children, protecting them, and helping them flourish.

\section{Discussion and Conclusion}

This article has examined poor black mothers' reported experiences with police to gain a better sense of how legal cynicism theory

12 D.C. Code $\$ 38-251$ (2012). 
fits with research showing that mothers in high-crime neighborhoods turn in intimate partners and children to the police, and that police receive more calls from the people and neighborhoods highest in cynicism. The findings encourage scholars to expand the study of cultural orientations about the law toward situated culture, or the culturally available strategies that emerge when orientations operate in real-life situations. Legal cynicism is a dynamic strategy that is part of a larger repertoire about legal authorities, and it is operates differently depending on the nature of moments of crime and disorder. Other strategies exist that are similarly triggered by circumstance. Four alternative strategies to legal cynicism emerged from this study: officer exceptionalism, domain specificity, therapeutic consequence-seeking, and institutional navigation.

This approach provides initial responses to some questions that remain unanswered in the legal cynicism and police legitimacy literatures. First, an approach that examines micro-level situational dynamics provides an additional dimension to how race and neighborhood matter for trust in the law. Both race and neighborhood play a role, but trust also varies depending on how law and legal authorities are operating within interactive moments. One way that survey research might better capture this dimension is by asking respondents at a more fine-grained level about their use of police in specific situations.

Second, this approach points to the intersubjective quality of trust. Trust is not a purely mental exercise, but is negotiated and deployed in emotionally charged moments between actors (see Katz 1988). These moments generate energies that carry over into future interactions with police, such that even if mothers still generally distrust police, possibilities for situation-specific trust remain (Collins 2004). Because distrust is high in this population along several axes (e.g., Burton et al. 2009; Desmond 2012; Levine 2013; Smith 2007, 2010), neighborhoods with concentrated poverty might also be thought of as neighborhoods with concentrated distrust. This study invites a broader exploration of how concentrated distrust fits into a broader milieu to affect the lives of poor families.

\section{Limitations}

There are several limitations of this exploratory study. One is that we know little about the frequency at which women use the strategies identified in this article. Although the study inquired about situations in which police were not called during the data collection process, instances were certainly omitted. It is extremely difficult to gain an accurate sense of "the denominator"- the number 
of times a person could have called the police but did not with data collected using retrospective surveys or interviews - as any number acquired through retrospective methods would likely be tainted with recall bias (see, e.g., Smith and Thomas 2003). The current study's primary empirical contribution is to provide understanding of mothers' explanations of their engagement with the police which, research shows, is non-negligible. The study cannot, however, explain the average or modal responses to crime or disorder. In future research, this design could perhaps be expanded to better capture which strategies are more or less salient over time, and which strategies are used to explain decisions not to notify the police of crime.

Second, this study was concerned with how to understand mothers' use of police. While focus on this critical population is a main benefit of the study, it is a limitation as well. Men and women without children are not studied, and they may interact with the police in different ways from my sample. What, if any, are the heterogeneous cultural conceptions of police for these groups? Are their strategies similar to mothers', or are there other ways that these groups understand the crime control system? Additionally, though this study did not detect systematic differences based on other variants such as age or prior incarceration, it is conceivable that situational trust would manifest differently among twenty-year-old mothers than among 50year-olds (see Bosick et al. 2012), and among those who have been incarcerated than those who have not been (see Buckler et al. 2011). These might be fruitful topics for further study.

\section{Race}

Although not a core aspect of the findings, race mattered a great deal to respondents' general opinions of the police and the crime control system. Race was rarely mentioned, however, when respondents told stories about specific interactions with the police. In encounters, problems with police were attributed to personality issues or police desire to assert authority. This is likely because of the demographic composition of D.C.'s police force: As explained above, 70 percent of D.C.'s police force is comprised of ethnic minorities, nearly all of whom are African-American. It seems that respondents would be less apt to attribute poor treatment to racism when the officer and respondent are of the same race, even if they see themselves as targets because of race. (However, some disagree-as Melissa notes, "You've got a lot of black police, and I think they kind of discriminate too.").

Race played a larger role when mothers described their general opinions on the criminal justice system and the types of 
neighborhoods in which they want to live. Most respondents express a belief that the system disregards the lives of poor African Americans. Respondents from neighborhoods undergoing racial and socioeconomic change ("gentrifying") report that police presence is high, and they are pleased to have the additional security. However, they believe the police are there to make the neighborhood safer for new (white) residents, not them. As Youlanda, who lives in a gentrifying neighborhood explains, "We see the police with the white people. We only see the police when the white people come in." ${ }^{3}$ These references to neighborhood racial composition point to the importance of keeping in mind the ecological and intersectional contexts in which situations occur. This article seeks to bring situations to light, but race and neighborhood context remain critical factors as well. These historically rooted factors create the backdrop against which microlevel factors operate. Future studies might explore the relationship between race, place, and situation in greater depth, expanding to a broader array of ethnic groups and delving deeper into police-community relations in the context of gentrification.

The findings lead to broader questions. Anderson (1999) explains that police may be called "only in a dire emergency" (p. 321). What does it mean, then, that respondents rely on police primarily to protect the home? What does safety mean to poor black mothers in the city? The results suggest that safety means familiarity with the actors who wield power in their daily lives. Safety means securing the home; although securing the neighborhood would be ideal, it is not as essential as the home and family (cf. Rosenblatt and DeLuca 2012; Wood 2014). In this process, the goal is to produce therapeutic outcomes, not punitive ones. One aspect of safety for these women is the importance of retaining support from the welfare state while keeping its harsh penalties at bay. More research is needed on the potentially divergent meanings of safety for people and the institutions tasked with keeping them secure.

The shift toward policing predicated on individual relationships with residents of high-poverty neighborhoods gives space for residents to develop more complex understandings of officers. Yet, despite developing positive relationships with some officers, respondents are deeply concerned about police corruption and violence at an institutional level. Respondents attribute occasional trust in the police to officer personalities and situation-

13 Desmond and Valdez (2013) found that police in Milwaukee patrolled neighborhoods that are 60 percent black more than neighborhoods with higher or lower percentages of black residents (p. 130). In DC, police deploy "an initial surge of officers" as a neighborhood begins to gentrify (Hermann 2012). 
specific circumstances rather than a trustworthy and effective police force. They often refer to media depictions of police as corrupt and incidents of police overreaction or violence when making cynical statements about police. Policing experts must keep in mind that the development of relationships between a few extraordinary beat officers and community members will not on its own build trust in the police as an institution. Residents will need to perceive force-wide respect and fairness in order to build a force-wide sense of trust and legitimacy.

The findings also indicate that police and poor black women have divergent beliefs about the incidents they are best equipped to address. Women want police to help them in or near the home, but officers are more interested in street crime. Police sometimes express frustration at their calls, especially when they call for help with nonviolent family altercations (see Reiss 1972). To foster a more robust sense of trust, police should take the problems that poor mothers bring to them seriously and treat them fairly. Respect in these interactions means more than politeness. It means recognizing that when mothers take the drastic step of calling the police about what might appear a minor situation or "family matter," these issues are, for them, Anderson's (1999) "dire emergencies" (see also Tyler and Huo 2002).

Mothers prefer to call the police when they foresee therapeutic consequences for the offender. Yet the crime control system currently produces only a limited set of therapeutic consequences. Many jurisdictions are developing rehabilitative alternatives to incarceration such as problem-solving courts and innovative forms of probation. Although further research is needed, the results imply that the expansion of these alternatives could produce a collateral benefit to law enforcement by increasing trust, legitimacy, and willingness to report crime.

What are the implications of a situational perspective for policing policy? Less-adversarial dynamics, community engagement, and specific moments of procedural justice in some DC neighborhoods (see Reisig and Parks 2004; Tyler and Huo 2002), have provided an opening where some respondents' cynical views on police momentarily yield. Programs such as Police Activity Leagues, in which police organize and participate in enrichment activities with at-risk youth, might be an example of an intervention that, carefully conceived, could over time expand the number and type of situations in which disadvantaged populations might trust and rely on law enforcement (see Institute for Municipal \& Regional Policy 2009). Recall Tara, who offered in her limited defense of police, "Sometimes they come out here and do stuff with the kids at the Rec." Policies that encourage officers to divert low-level offenders to community resources without first 
arresting them (see, e.g., Beckett 2014) might also indirectly increase community trust by making it more possible for police involvement to produce therapeutic consequences. ${ }^{14}$

These extrapolations are necessarily cautious given the nature of this study. Nonetheless, a situational perspective might sensitize policy makers to the potentially considerable effects that finergrained policy and practice, rather than broad policy commitments (e.g., "community policing"), might have on community members' highly contextualized daily experiences of crime control, and correspondingly, police legitimacy. This perspective might also sensitize policy makers to the difficulty of mothering in the context of poverty: Because of the retraction of noncriminal social systems (e.g., Edin and Shaefer 2015), the criminal justice system has become one of few socially sanctioned avenues through which mothers can procure resources and security for their families.

This article offers a situational perspective as an expanded mandate for research on the cultural context of policecommunity relations. Previous research has established important facts with respect to the types of people and neighborhoods least likely to trust the police, and has demonstrated the negative effects of legal cynicism on various aspects of social life. An additional body of research should explore in greater depth how legal trust operates across complex situations.

\section{References}

Abrego, Leisy (2011) "Legal Consciousness of Undocumented Latinos:Fear and Stigma as Barriers to Claims-Making for First- and 1.5-Generation Immigrants," 45 Law \& Society Review 33770.

Anderson, Elijah (1990) Streetwise: Race, Class, and Change in an Urban Community. Chicago: Univ. of Chicago.

(1999) Code of the Street: Decency, Violence, and the Moral Life of the Inner City. New York: Norton.

Avakame, Edem F., James J. Fyfe, \& Candace McCoy (1999) “'Did You Call the Police? What Did They Do?' An Empirical Assessment of Black's Theory of Mobilization of Law," 16 Justice Q. 765-92.

Baumer, Eric P. (2002) "Neighborhood Disadvantage and Police Notification by Victims of Violence,” 40 Criminology 579-616.

Bell, Monica C., et al. (2016) "Beyond the Culture of Poverty: Meaning-Making among Low-Income Populations around Family, Neighborhood, and Work," in Stone, J.,

14 In contrast, "zero-tolerance" or "broken windows" policing has been associated with declining trust among typically legally cynical populations (Greene 1999; see Wilson and Kelling 1982). Black and Latino plaintiffs in Floyd v. City of New York, the 2013 case that struck down New York City's "stop-and-frisk" policy, testified that repeated stops and unjustified searches made them feel distrustful of the police (2013: 557; see also Collins 2007). The gradual incorporation of police paramilitary units into traditional police forces (Kraska and Kappeler 1997) similarly hinders police efforts to develop the nonadversarial relationships crucial for increasing trust. 
Dennis, R., Rizova, P., Smith, A., \& Hou X, eds., Wiley-Blackwell Encyclopedia of Race, Ethnicity, and Nationalism. Hoboken: Wiley-Blackwell.

Beckett, Katherine (2014) Seattle's Law Enforcement Assisted Diversion Program: Lessons Learned from the First Two Years. Seattle: Univ. of Washington.

Berger, Peter L., \& Thomas Luckmann (1966) The Social Construction of Reality. New York: Penguin.

Black, Donald (1976) The Behavior of Law. New York: Academic Press. (1983) "Crime as Social Control," 48 American Sociological Review 34-45.

Blumer, Herbert (1969) Symbolic Interactionism: Perspective and Method. Englewood Cliffs: Prentice-Hall.

Bobo, Lawrence D., \& Victor Thompson (2006) "Unfair by Design: The War on Drugs, Race, and the Legitimacy of the Criminal Justice System," 73 Social Research $445-72$.

Bosick, Stacey, et al. (2012) "Reporting Violence to the Police:Predictors through the Life Course," $40 \mathrm{~J}$. of Criminal Justice 441-51.

Bourdieu, Pierre (1998) Acts of Resistance: Against the Tyranny of the Market. New York: New Press.

Braman, Donald (2004) Doing Time on the Outside: Incarceration and Family Life in Urban America. Ann Arbor: Univ. of Michigan.

Brooks, Richard R. W. (2000) "Fear and Fairness in the City: Criminal Enforcement and Perceptions of Fairness in Minority Communities," 73 Southern California Law Rev. $1219-1275$.

Brown, Jodi, \& Patrick Langan. 2001. Policing and Homicide, 1976-98. Washington: Department of Justice.

Brunson, Rod K. (2007) “'Police Don't Like Black People': African-American Young Men's Accumulated Police Experiences," 6 Criminology \& Public Policy 71-101.

Brunson, Rod K., \& Jacinta Gau (2015) "Officer Race Versus Macro-Level Context: A Test of Competing Hypotheses About Black Citizens' Experiences with and Perceptions of Black Police Officers," 61 Crime \& Delinquency 213-242.

Brunson, Rod K., \& Jody Miller (2006) "Gender, Race and Urban Policing: The Experience of African American Youths," 20 Gender E Society 531-52.

Buckler, Kevin, et al. (2011) "Racial and Ethnic Perceptions of Injustice: Does Prior Personal and Vicarious Incarceration Experience Alter the Racial/Ethnic Gap in Perceptions of Injustice?," 36 Criminal Justice Rev. 269-90.

Buntin, John (2012) "Cathy Lanier Changes Policing in D.C. and Maybe Nation." Governing. July, Available at: http://www.governing.com/topics/public-justice-safety/ chief-cathy-lanier-changes-policing.html (accessed 31 December 2013).

Burton, Linda M., et al. (2009) "The Role of Trust in Low-Income Mothers' Intimate Unions," $71 \mathrm{~J}$. of Marriage and Family 1107-127.

Carr, Patrick J., Laura Napolitano, \& Jessica Keating (2007) "We Never Call the Cops and Here is Why: A Qualitative Examination of Legal Cynicism in Three Philadelphia Neighborhoods," 45 Criminology 701-36.

Clampet-Lundquist, Susan, Patrick J. Carr, \& Maria Kefalas (2015) "The Sliding Scale of Snitching: A Qualitative Examination of Snitching in Three Philadelphia Communities," 30 Sociological Forum 265-85.

Carson, E. Ann, \& William Sabol (2012) Prisoners in 2011. Washington: Department of Justice.

Charmaz, Kathy (2006) Constructing Grounded Theory. London: Sage.

Chicago Commission on Race Relations (1922) The Negro in Chicago. Chicago: Univ. of Chicago.

Clarke, Adele E. (2005) Situational Analysis: Grounded Theory after the Postmodern Turn. Thousand Oaks: SAGE.

Cochran, Joshua, \& Patricia Warren (2012) "Racial, Ethnic, and Gender Differences in Perceptions of the Police: The Salience of Officer Race Within the Context of Racial Profiling," 28 J. of Contemporary Criminal Justice 206-27. 
Collins, Patricia Hill (1991) Black Feminist Thought: Knowledge, Consciousness, and the Politics of Empowerment. New York: Routledge.

Collins, Randall (2004) Interaction Ritual Chains. Princeton: Princeton.

Collins, Reed (2007) "Strolling While Poor: How Broken-Windows Policing Created a New Crime in Baltimore," 14 Georgetown J. on Poverty Law and Policy 419-39.

Comfort, Megan (2008) Doing Time Together: Love and Family in the Shadow of the Prison. Chicago: Univ. of Chicago.

Correll, Joshua, et al. (2007) "Across the Thin Blue Line: Police Officers and Racial Bias in the Decision to Shoot," 92 J. of Personality and Social Psychology 1006-023.

Crenshaw, Kimberle (1989) "Demarginalizing the Intersection of Race and Sex: A Black Feminist Critique of Antidiscrimination Doctrine, Feminist Theory, and Antiracist Politics," 140 University of Chicago Legal Forum 139-67.

Desmond, Matthew (2012) "Disposable Ties and the Urban Poor," 117 American J. of Sociology 1295-335.

Desmond, Matthew, \& Andrew Papachristos (2016) "Police Violence and Citizen Crime Reporting in the Black Community." Unpublished manuscript.

Desmond, Matthew \& Monica Bell (2015) "Housing, Poverty, and the Law," 11 Annual Review of Law \& Social Science 9.1-9.21.

Desmond, Matthew, \& Nicol Valdez (2013) "Unpolicing the Poor: Consequences of Third-Party Policing for Inner-City Women," 78 American Sociological Rev. 117-41.

Du Bois, W. E. Burghardt (1904) Some Notes on Negro Crime, Especially in Georgia. Atlanta: Atlanta University.

Edin, Kathryn J. \& H. Luke Shaefer (2015) \$2.00 a Day: Living on Almost Nothing in America. New York: Houghton Mifflin.

Edin, Kathryn, \& Maria Kefalas (2005) Promises I Can Keep: Why Poor Women Put Motherhood Before Marriage. Berkeley: Univ. of California.

Edin, Kathryn, \& Laura Lein (1997) Making Ends Meet: How Single Mothers Survive Welfare and Low-Wage Work. New York: Russell Sage.

Eitle, David, Lisa Stolzenberg \& Stewart D'Alessio (2005) "Police Organizational Factors, the Racial Composition of the Police, and the Probability of Arrest," 22 Justice Q. 30-57.

Ewick, Patricia, \& Susan S. Silbey (1998) The Common Place of Law. Chicago: Univ. of Chicago.

Felson, Richard, et al. (2002) "Reasons for Reporting and Not Reporting Domestic Violence to the Police," 40 Criminology 617-48.

Fine, Gary Alan, \& Corey Fields (2008) "Culture and Microsociology: The Anthill and the Veldt," 619 Annals of the American Academy of Political and Social Sciences 130-48.

Fontaine, Jocelyn, Joshua Markman, \& Carey Nadeau (2010) Promising Practices of the District of Columbia Metropolitan Police Department. Washington: Crime Policy Institute.

Garland, David (2001) The Culture of Control. Chicago: Univ. of Chicago.

Gau, Jacinta M. (2015) "Procedural Justice, Police Legitimacy, and Legal Cynicism: A Test for Mediation Effects," 16 Police Practice and Research: An International J. 402-15.

Geertz, Clifford (1973) The Interpretation of Cultures. New York: Basic Books.

Geller, Amanda B., \& Marah A. Curtis (2011) "A Sort of Homecoming: Incarceration and the Housing Security of Urban Men," 40 Social Science Research 1196-213.

Giddens, Anthony (1990) The Consequences of Modernity. Stanford: Stanford.

Gilliom, John (2001) Overseers of the Poor: Surveillance, Resistance, and the Limits of Privacy. Chicago: Univ. of Chicago.

Glaser, Barney G., \& Anselm Strauss (1967) The Discovery of Grounded Theory: Strategies for Qualitative Research. Chicago: Aldine.

Goffman, Alice. 2009. "On the Run: Wanted Men in a Philadelphia Ghetto," 74 American Sociological Rev. 339-57.

Goffman, Erving (1974) Frame Analysis: An Essay on the Organization of Experience. Cambridge, MA: Harvard.

Greene, Judith A. (1999) "Zero Tolerance: A Case Study of Police Policies and Practices in New York City," 45 Crime \& Delinquency 171-187. 
Gustafson, Kaaryn (2011) Cheating Welfare: Public Assistance and the Criminalization of Poverty. New York: NYU.

Hagan, John \& Celesta Albonetti (1982) "Race, Class, and the Perception of Criminal Injustice in America," 88 American J. of Sociology 329-55.

Hannerz, Ulf (1969) Soulside: Inquiries into Ghetto Culture and Community. Chicago: Univ. of Chicago.

Harding, David J. (2007) "Cultural Context, Sexual Behavior, and Romantic Relationships in Disadvantaged Neighborhoods," 72 American Sociological Rer. 341-64.

Harris, Alexes, Heather Evans, \& Katherine Beckett (2010) "Drawing Blood from Stones: Legal Debt and Social Inequality in the Contemporary United States," 115 American J. of Sociology 1753-799.

Hermann, Peter (2012) “D.C. Police Measure Up-and-coming Neighborhoods.” Washington Post, Aug. 4. Available at: http://www.washingtonpost.com/local/crime/ dc-police-chief-says-predicting-crime-is-way-to-protect-new-development-in-district/ 2012/08/04/98a3ac50-dd60-11e1-9ff9-1dcd8858ad02_story.html (accessed 18 March 2014).

Hernandez, Diana (2010) “'I'm Gonna Call My Lawyer': Shifting Legal Consciousness at the Intersection of Inequality," 88 Studies in Law, Politics, and Society 329-55.

Institute for Municipal \& Regional Policy (2009) Evaluation of the Waterbury Police Activity League. New Britain: CCSU.

Johnson, Marilynn S. (2003) Street Justice: A History of Police Violence in New York City. Boston: Beacon.

Jones, Nikki (2010) Between Good and Ghetto: African American Girls and Inner-City Violence. Camden: Rutgers.

Katz, Jack (1988) Seductions of Crime. New York: Basic Books.

Kennedy, Randall (1997) Race, Crime, and the Law. New York: Vintage Books.

Kirk, David, \& Andrew V. Papachristos (2011) "Cultural Mechanisms and the Persistence of Neighborhood Violence," 116 American J. of Sociology 1190-233.

Kirk, David, \& Mauri Matsuda (2011) "Legal Cynicism, Collective Efficacy, and the Ecology of Arrest," 35 Criminology 277-336.

Kraska, Peter \& Victor E. Kappeler (1997) "Militarizing American Police: The Rise and Normalization of Paramilitary Units," 44 Social Problems 1-18.

Lamont, Michèle, \& Mario Small (2008) "How Culture Matters: Enriching Our Understanding of Poverty," in The Colors of Poverty: Why Racial and Ethnic Disparities Persist, edited by D. Harris and A. Lin. New York: Russell Sage. 76-102

LaRossa, Ralph (2005) "Grounded Theory Methods and Qualitative Family Research," $67 \mathrm{~J}$. of Marriage and Family 837-57.

Levine, Judith A. (2013) Ain't No Trust: How Bosses, Boyfriends, and Bureaucrats Fail LowIncome Mothers and Why It Matters. Berkeley: Univ. of California.

Luhmann, Niklas (1979) Trust and Power. Chichester: Wiley.

Mead, George Herbert (1934) Mind, Self and Society. Chicago: Univ. of Chicago.

Meares, Tracey L., \& Dan M. Kahan (1998) "The Coming Crisis of Criminal Procedure," 86 Georgetown Law J. 1153-1185.

Merry, Sally Engle (1990) Getting Justice and Getting Even: Legal Consciousness among Working-Class Americans. Chicago: Univ. of Chicago.

Moskos, Peter. 2008. Cop in the Hood. Princeton: Princeton Univ. Press.

Muhammad, Khalil Gibran (2010) The Condemnation of Blackness. Cambridge: Harvard.

Muller, Christopher \& Daniel Schrage (2014) "Mass Imprisonment and Trust in the Law," 651 Annals of the American Academy of Political and Social Science 139-58.

National Advisory Commission on Civil Disorders (1967) Report of the National Advisory Commission on Civil Disorders. Washington: GPO.

Nix, Justin, et al. (2015) "Trust in the Police: The Influence of Procedural Justice and Perceived Collective Efficacy," 61 Crime \& Delinquency 610-40.

Norton, Matthew (2014) "Mechanisms and Meaning Structures," 32 Sociological Theory $162-87$. 
Nurse, Anne (2002) Fatherhood Arrested: Parenting from Within the Juvenile Justice System. Nashville: Vanderbilt.

Obasogie, Osagie (2013) "Foreword: Critical Race Theory and Empirical Methods," 3 U.C. Irvine Law Rev. 183-86.

Papachristos, Andrew, Tracey L. Meares, \& Jeffrey Fagan (2012) "Why Do Criminals Obey the Law? The Influence of Legitimacy and Social Networks on Active Gun Offenders," 102 J. of Criminal Law and Criminology 397-440.

Patterson, Orlando (2000) "Taking Culture Seriously: A Framework and Afro-American Illustration," in Harrison, L. E., \& Huntington, S. P., ed., Culture Matters. New York: Basic Books. 202-18

Pattillo-McCoy, Mary (1999) Black Picket Fences: Privilege and Peril Among the Black Middle Class. Chicago: Univ. of Chicago.

Paul-Emile, Kimani (2015) "Foreword: Critical Race Theory and Empirical Methods Conference," 83 Fordham Law Rev. 2953-960.

Plant, E. Ashby, \& B. Michelle Peruche (2005) "The Consequences of Race for Police Officers' Responses to Criminal Suspects,” 16 Psychological Science 180-83.

President's Task Force on 21st Century Policing (2015) Final Report of the President's Task Force on 21st Century Policing. Washington: COPS.

Reisig, Michael D., \& Roger B. Parks (2004) "Can Community Policing Help the Truly Disadvantaged?," 50 Crime \& Delinquency 139-67.

Reisig, Michael D., \& Roger Parks (2000) "Experience, Quality of Life, and Neighborhood Context: A Hierarchical Analysis of Satisfaction with Police," 17 Justice $Q$. 607-30.

Reiss, Albert J., Jr. (1972) The Police and the Public. 3rd printing. New Haven: Yale.

Rios, Victor M. (2011) Punished: Policing the Lives of Black and Latino Boys. New York: NYU.

Roberts, Dorothy (2002) Shattered Bonds: The Color of Child Welfare. New York: Basic Books.

Rosenblatt, Peter, \& Stefanie DeLuca (2012) “'We Don't Live Outside, We Live in Here': Neighborhood and Residential Mobility Decisions Among Low-Income Families," 11 City \& Community 254-84.

Sampson, Robert J. (2012) Great American City: Chicago and the Enduring Neighborhood Effect. Chicago: Univ. of Chicago.

Sampson, Robert J., \& Dawn Jeglum Bartusch (1998) "Legal Cynicism and (Subcultural?) Tolerance of Deviance: The Neighborhood Context of Racial Differences," 32 Law E Society Rev. 777-804.

Schaible, Lonnie, \& Lorine A. Hughes (2012) "Neighborhood Disadvantage and Reliance on the Police," 58 Crime \& Delinquency 245-74.

Schudson, Michael (1989) "How Culture Works: Perspectives from Media Studies on the Efficacy of Symbols," 18 Theory and Society 153-80.

Sharp, Elaine \& Paul E. Johnson (2009) "Accounting for Variation in Distrust of Local Police," 26 Justice Q. 157-82.

Short, James F. Jr., \& Fred Strodtbeck (1965) Group Process and Gang Delinquency. Chicago: Univ. of Chicago.

Shriver, Edwin, \& Kurt Hugenberg (2010) "Power, Individuation, and the Cross-Race Recognition Deficit," 46 J. of Experimental Social Psychology 767-74.

Silbey, Susan S. (2005) "After Legal Consciousness," 1 Annual Rev. of Law and Social Science 323-68.

Smith, James P., \& Duncan Thomas (2003) "Remembrances of Things Past: Test-Retest Reliability of Retrospective Migration Histories," $166 \mathrm{~J}$. of the Royal Statistical Society, Series A 23-49.

Smith, Sandra Susan (2007) Lone Pursuit: Distrust and Defensive Individualism Among the Black Poor. New York: Russell Sage. - (2010) "Race and Trust," Annual Rev. of Sociology 36:453-475.

Soss, Joe, Richard Fording, \& Sanford Schram (2011) Disciplining the Poor: Neoliberal Paternalism and the Persistent Power of Race. Chicago: Univ. of Chicago. 
Stuart, Forrest (2011) "Race, Space, and the Regulation of Surplus Labor: Policing African-Americans in Los Angeles' Skid Row," 13 Souls: A Critical J. of Black Politics, Culture, and Society 197-212.

Sun, Ivan \& Brian Payne (2004) "Racial Differences in Resolving Conflicts: A Comparison between Black and White Police Officers," 50 Crime E Delinquency 516-41.

Suk, Jeannie (2009) At Home in the Law. New Haven: Yale.

Swidler, Ann (2001) Talk of Love: How Culture Matters. Chicago: Univ. of Chicago. (1986) "Culture in Action: Symbols and Strategies." 51 American Sociological Rev. 273-86.

Sykes, Jennifer (2011) "Negotiating Stigma: Understanding Mothers' Responses to Accusations of Child Neglect," 33 Children and Youth Services Rev. 448-56.

Terrill, William \& Michael D. Reisig (2003) "Neighborhood Context and Police Use of Force," $40 \mathrm{~J}$. of Research in Crime and Delinquency 291-321.

Thomas, Kimberly (2013) "Interpersonal Power in the Criminal System," 50 American Criminal Law Rev. 247-76.

Thomas, W. I., \& Dorothy S. Thomas (1928) The Child in America: Behavior Problems and Programs. New York: Knopf.

Tyler, Tom R., \& Yuen J. Huo (2002) Trust in the Law. New York: Russell Sage.

Uslaner, Eric M. (2002) The Moral Foundations of Trust. New York: Cambridge.

Venkatesh, Sudhir Alladi (1997) "The Social Organization of Street Gang Activity in an Urban Ghetto," 103 American J. of Sociology 82-111.

(2000) American Project. Cambridge, MA: Harvard.

Wacquant, Loïc (2009) Punishing the Poor. Durham: Duke.

Waller, Maureen R. (2002) My Baby's Father: Unmarried Parents and Paternal Responsibility. Ithaca: Cornell.

Websdale, Neil (2001) Policing the Poor. Boston: Northeastern.

Weitzer, Ronald \& Steven A. Tuch (2004) "Race and Perceptions of Police Misconduct." 51 Social Problems 305-25.

Weitzer, Ronald, Steven A. Tuch \& Wesley G. Skogan (2008) "Police-Community Relations in a Majority-Black City," $48 \mathrm{~J}$. of Research in Crime and Delinquency 398-428.

Werthman, Carl \& Irving Piliavin (1967) "Gang Members and the Police," in The Police: Six Sociological Essays, Bordua, D. J., eds. New York: Wiley. 56-98

Western, Bruce (2006) Punishment and Inequality in America. New York: Russell Sage.

Westley, William A. (1953) "Violence and the Police," 59 American J. of Sociology 34-41.

Wildeman, Christopher, \& Sara Wakefield (2014) "The Long Arm of the Law: The Concentration of Incarceration in Families in the Era of Mass Incarceration," $17 \mathrm{~J}$. of Gender, Race, and Justice 347-89.

Wilson, James Q., \& George L. Kelling (1982) "Broken Windows: The Police and Neighborhood Safety," 249 Atlantic Monthly 29-38.

Wilson, William Julius (2009) More Than Just Race: Being Black and Poor in the Inner City. New York: Norton.

Wood, Holly (2014) "When Only a House Makes a Home: How Home Selection Matters in the Residential Mobility Decisions of Lower-Income, Inner-City AfricanAmerican Families," 88: Social Service Rev. 264-94.

\section{Cases Cited}

Floyd ข. City of New York, 959 F. Supp. 2d 540 (S.D.N.Y. 2013).

Monica C. Bell is a Ph.D. Candidate in Sociology and Social Policy and Harvard University, a research associate with the Justice Collaboratory at Yale Law School, and a Climenko Fellow at Harvard Law School. 